\title{
ITGA4 Gene
}

National Cancer Institute

\section{Source}

National Cancer Institute. IT GA4 Gene. NCI Thesaurus. Code C97747.

This gene is involved in fibronectin binding and leukocyte migration. 